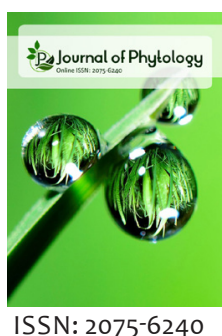

Received: January 16, 2020 Revised: February 6, 2021

Accepted: February 8, 2021 Published: March 18, 2021

*Corresponding Author: Sarwoko Mangkoedihardjo, E-mail: prosarwoko@gmail.com

\section{Indoor phytoremediation using decorative plants: An overview of application principles}

\author{
Harida Samudro', Sarwoko Mangkoedihardjo ${ }^{2 *}$ \\ 'Department of Architecture, Universitas Islam Negeri (UIN) Maulana Malik Ibrahim (State Islamic University of \\ Malang), Malang, Indonesia, 'Department of Environmental Engineering, Institut Teknologi Sepuluh Nopember \\ (ITS), Surabaya, Indonesia
}

\begin{abstract}
A healthy and sustainable indoor space was one of the goals of a building, which was an important concern of architects in designing and using it. Design arrangements can be approached physically, such as the use of air vents, lighting, and layout arrangements. However, now the paradigm of using a natural approach has been intensive. In this regard, this paper focuses on the greening of indoor spaces, both for the prevention and restoration of indoor room quality. The study methodology was a survey of existing research results in many countries, and a selection of up-to-date, current data. The results of the literature research obtained are related to the purpose of indoor greening, which is none other than to achieve the goal of green building. Its main target was biodiversity in the prevention of negative health effects and indoor phytoremediation.
\end{abstract}

KEYWORDS: Sustainable indoor, natural approach, phytoremediation, biodiversity

\section{INTRODUCTION}

Green building has become a paradigm of comfort and health building aimed at human health and the environment. Especially is the effort to create a healthy indoor space, which is generally related to aesthetics and comfort. The use of environmentally friendly building materials has been used, including in the use of furniture (Ragheb et al., 2016; Masood et al., 2017; Pryadko, 2018). However, the development of furniture using excessive architectural and decorative materials can release volatile organic compounds (VOCs). These substances are often released at concentrations above the quality standard in residential buildings, especially in newly decorated houses (Nakaoka et al., 2014; Nakaoka et al., 2018). VOCs are representations of the most important contaminants in the indoor environment, and of course affect the health of their occupants (Rovelli et al., 2019; Deng \& Deng, 2018; Bogerd et al., 2020). Indoor VOCs in new buildings were found 10-15 times more than in old buildings in addition to the effect of humidity and temperature (Smith et al., 2017; Zhou et al., 2017; Chiang et al., 2020). For tropical countries, such as Indonesia, this issue is very important and needs serious attention.

Generally, people stay indoors at least $80 \%$ of their time (Deng \& Deng, 2018), even more than 90\% (Wang et al., 2008), therefore, the quality of a healthy environment is very important for residents. Natural environmental health can be obtained through greening the room, due to the process of plants to eliminate environmental pollutants, which is known as the phytoremediation process (Pettit et al., 2020; Pettit et al., 2018; Zhang et al., 2020). Efforts to improve indoor quality through the phytoremediation process have been conducted in many countries and are the main discussion in this paper. The use of ornamental plants to eliminate indoor pollutants makes the environmental health function stronger (Zorić et al., 2019; Samudro \& Mangkoedihardjo, 2020), and simultaneously to ensure the availability of oxygen along with other aesthetic values. Within this framework, this paper specifically discusses the elimination of VOCs using indoor ornamental plants, along with the idea of its basic implementation, with the aim of making buildings healthy from the start and their sustainable use.

\section{METHODS}

The method of reducing indoor contamination uses natural processes of ornamental plants. Pollution removal by plants, known as phytoremediation is an effective and efficient technique to prevent damage and restore indoor air quality. Some plants show a high potential to remove formaldehyde from indoor air by means of absorption by plant stems or leaves, plant cell metabolism and decomposition of root microorganisms

Copyright: $\odot$ The authors. This article is open access and licensed under the terms of the Creative Commons Attribution License (http://creativecommons.org/licenses/by/4.0/) which permits unrestricted, use, distribution and reproduction in any medium, or format for any purpose, even commercially provided the work is properly cited. Attribution - You must give appropriate credit, provide a link to the license, and indicate if changes were made. 
(Teiri et al., 2020; Kwang et al., 2008). Several studies have shown the elimination of air pollutants, which massively represent the ability of potted soil ecosystems, a medium for plant growth (Newman \& Reynolds, 2004; Wang et al., 2014; Agarwal et al., 2019).

This study is based on a literature survey of existing research results. Hundreds of research topics are available around the world. This proves that the problem of indoor pollutants and the solution using indoor plants has become the world's attention (Pettit et al., 2020; Cruz et al., 2015; Sevik et al., 2018). For this study, the literatures were selected, which are relevant and current.

Of particular interest to this study are the following two related topics. Firstly, it is various studies on the ability of indoor plants to absorb and/or eliminate VOCs, especially formaldehyde from the room. Secondly, there is an idea related to the application of indoor greening, especially setting space priorities based on the potential for air pollutants generation.

\section{RESULTS AND DISCUSSION}

\section{Indoor Contamination}

NASA Clean Air Study has recorded the results of quite intensive studies on various types of indoor ornamental plants that are specific for the elimination of VOCs ("NASA Clean Air Study," 2020). Of course, this data can be a starting point for the development of further studies. Especially aimed at areas that have specific types of ornamental plants, but have not received attention for their utilization.

In general, new buildings cannot be separated from the need to use paint, as well as new furniture, mostly using paint. Paints and their various products contain thousands of types of chemicals (Keith, 2011; "Painting, Firefighting, and Shiftwork." 2010; Onesmo \& Rongo, 2018). One of them is formaldehyde, which is present most frequently in paints, and which occurs in the air as a colorless gas releasing a strong odor. It is present in many building materials such as plywood, particleboard, curtains, and other types of foam insulation, as well as many other pieces of furniture to be named individually. Thus, the main sources of formaldehyde in the room include furniture, wood products, wallpaper, cleaners, paints, adhesives, oils, cosmetics, electronic goods, fuels and cigarette smoke (Teiri et al., 2020; van den Broek et al., 2020). In addition, formaldehyde also arises from kitchen activities, building hygiene maintenance, and even personal hygiene products for residents (Indoor Air Quality, 2016; Brandão et al., 2018). In the course of time using existing buildings and furniture, formaldehyde can be reduced because it degrades over time. However, quick and early safeguards are best to prevent harmful exposures to residents and/or occupants.

\section{Indoor Phytoremediation}

From the experimental results, the negative effects of formaldehyde on test living organisms indicate it has an impact on the respiratory system, blood health, leukemia, brain, and other carcinogenic risks (Duan et al., 2018; Ge et al., 2019; Zhang et al., 2009; Hadei et al., 2018; Teiri et al., 2018a). In addition is sick building syndrome (Ghaffarianhoseini et al., 2018; Nakayama et al., 2019), such as headaches, nausea, dizzy, eye irritation, muceous membrane, drowsiness, fatigue and discomfort. A recent development used a lower limit for formaldehyde below $1 \%$, to prevent sick building syndrome (Suzuki et al., 2019).

Quite a number of researchers conducted experiments to eliminate formaldehyde using indoor ornamental plants (Meng \& Ji, 2012; Wang et al., 2020). An experiment was carried out to measure the efficiency of potted Areca palm, which aims to eliminate total organic pollutants in indoor air. The experiment used 9 potted plants, which were carried out for four months in real indoor. It was found that the elimination efficiency was close to $90 \%$ (Bhargava et al., 2020). Areca palm has also been studied and proven its ability to eliminate toluene and xylene ("NASA Clean Air Study," 2020). Other similar research was found by three types of tropical plants, namely Dracaena fragrans, Rhapis excelsa and Nephrolepis exaltata. All of them have the same ability to remove gases from indoor air (Jasmin et al., 2012).

Meanwhile, the formaldehyde content in indoor air is eliminated by the one of the palm species, namely Chamaedorea elegans, and with various concentrations of formaldehyde up to $16 \mathrm{mg} / \mathrm{m} 3$ over a 48 hour period. The results obtained showed that the maximum purification capacity of formaldehyde was about $1.5 \mathrm{mg} / \mathrm{m} 2 /$ hour, which was achieved with the maximum concentration exposure for 2 days. Other results show that the efficiency was obtained by a ratio of plant area and floor area of $70 \%$ : $30 \%$. Bright room eliminates more formaldehyde than dark room (Teiri et al., 2018b).

Experiments on light and dark spaces for formaldehyde elimination were also carried out using Ficus benjamina L. and Ficus japonica plants. The aerial parts of both species reduced formaldehyde concentrations during the day, but only slightly removed at night. Meanwhile, the root is capable of removing large amounts of formaldehyde during the day and night. The effectiveness of roots in eliminating formaldehyde was mainly due to microorganisms and roots. The results of this study indicate that enhance rhizodegradation was the main process of removing formaldehyde (Kwang et al., 2008; Aydogan \& Montoya, 2011).

Formaldehyde elimination was also studied in experiments using plants from the Liliaceae, Agavaceae and Araceae families. The volume of space is $0.8 \mathrm{~m} 3$ containing formaldehyde with an initial concentration of $15 \mathrm{mg} / \mathrm{m} 3$. Within 3 days, it was recommended that most species from these plant families are effective in removing formaldehyde. However, Philodendron selloum is the least resistant to formaldehyde exposure (Zhou et al., 2011).

Experiments using one of the common interior plants of the fern species (Nephrolepis obliterata) were aimed at eliminating 
formaldehyde from the air. The maximum concentration of exposed formaldehyde vapor was $11 \mathrm{mg} / \mathrm{m} 3$ ) for 48 hours. The results revealed that $N$. obliterata plants efficiently removed formaldehyde from polluted air at least $90 \%$ during the exposure time. It was also known that the soil and roots contribute little to formaldehyde elimination, which is about $25 \%$. The plant species tested have high potential in improving the interior environment from exposure to formaldehyde (Teiri et al., 2018b).

\section{Indoor Biodiversity}

The importance and necessity of biodiversity for the implementation of phytoremediation has been corroborated by various studies on the elimination of VOCs, which originate from energy use, namely known as benzene, toluene, ethylbenzene, and xylene (BTEX). Some of the most recent data among the existing studies are presented as follows. The efficiency of toluene phytoremediation increased by an average of $156 \mathrm{mg} / \mathrm{m} 3 /$ hour $/ \mathrm{m} 2$ leaves of Pinus densilora and Salvia elegans (Kwang Jin Kim et al., 2011). Efficient removal of toluene and xylene was achieved using indoor plants (Schefflera actinophylla and Ficus benghalensis). The removal efficiency of toluene and xylene was around $13 \mu \mathrm{g} / \mathrm{m} 3 / \mathrm{m} 2$ leaf area for 24 hours by S. actinophylla, however F. benghalensis was only able to remove about half of it. As well as, about half the concentrations of toluene and xylene was translocated from the air to the root zone through the stem, which indicates that the root zone plays an important role in this elimination process (Kim et al., 2016).

There is intensive research to filter out dozens of plant species that are capable of eliminating many VOCs gases. For exposure to each gas as much as 10 ppm within 6 hours, it was found that Hemigraphis alternata, Hedera helix, Hoya carnosa, and Asparagus densive chlorus had the highest removal efficiency for all pollutants (Yang et al., 2009). Other types of plants have different and lower removal efficiencies. The difference in efficiency between plant species indicates the need, the importance and necessity of biodiversity in the processing of pollutants by plants (Samudro \& Mangkoedihardjo, 2020; Samudro \& Mangkoedihardjo, 2020; Ren et al., 2017).

The average benzene removal efficiency of $70 \%$ was achieved by four common ornamental plants, namely Epipremnum aureum, Chlorophytum comosum, Hedera helix and Echinopsis tubiflora. The last type of plant is interesting to observe, that the high ability of removal efficiency is due to its high ability to transpiration and high chlorophyll content, which the other three types of plants did not have (Gong et al., 2019). The high transpiration of plants indicates that they need a lot of watering while they are used for room remediation. Likewise, the high chlorophyll content of plants indicates the need for sufficient sunlight to utilize it. Therefore, planting conditioning and maintenance needs to be considered (Mangkoedihardjo \& Samudro, 2014; Ni et al., 2019) in order to support the maximum capacity of plants to eliminate polluting gases. Thus, the application of biodiversity, including the diversity of plant conditions and ways of maintaining them, is able to eliminate many pollutants maximally.

\section{CONCLUSION}

Biodiversity in indoor phytoremediation is necessary and important. Apart from differences in the ability between plant species to eliminate contaminants, it is also due to the ability of plant parts to process them. There are types of plants whose aerial parts are less capable of eliminating gases, but in fact their ability is more in the root zone, which has the support of microorganisms to eliminate contaminants. Thus, the diversity of phytoremediation processes and microorganisms becomes biological diversity to maintain the health of the indoor environment.

\section{REFERENCES}

Agarwal, P., Sarkar, M., Chakraborty, B., \& Banerjee, T. (2019). Phytoremediation of Air Pollutants. Phytomanagement of Polluted Sites, 221-241. https://doi.org/10.1016/b978-0-12-813912-7.00007-7

Aydogan, A., \& Montoya, L. D. (2011). Formaldehyde removal by common indoor plant species and various growing media. Atmospheric Environment, 45(16), 2675-2682. https://doi.org/10.1016/j. atmosenv.2011.02.062

Bhargava, B., Malhotra, S., Chandel, A., Rakwal, A., Kashwap, R. R., \& Kumar, S. (2020). Mitigation of indoor air pollutants using Areca palm potted plants in real-life settings. Environmental Science and Pollution Research, 28, 8898-8906. https://doi.org/10.1007/s11356020-11177-1

Bogerd, N. van den, Dijkstra, S. C., Tanja-Dijkstra, K., Boer, M. R. de, Seidell, J. C., Koole, S. L., \& Maas, J. (2020). Greening the classroom: Three field experiments on the effects of indoor nature on students' attention, well-being, and perceived environmental quality. Building and Environment, 171(15). 106675. https://doi.org/10.1016/j. buildenv.2020.106675

Brandão, P. F., Ramos, R. M., \& Rodrigues, J. A. (2018). GDME-based methodology for the determination of free formaldehyde in cosmetics and hygiene products containing formaldehyde releasers. Analytical and Bioanalytical Chemistry, 410(26), 6873-6880. https://doi. org/10.1007/s00216-018-1287-0

Chiang, C., Bånkestad, D., \& Hoch, G. (2020). Reaching natural growth: The significance of light and temperature fluctuations in plant performance in indoor growth facilities. Plants, 9(10), 1-18. https:// doi.org/10.3390/plants9101312

Cruz, M. D., Christensen, J. H., \& Müller, R. (2015). Indoor plants as air cleaners. Acta Horticulturae, 1093, 133-137. https://doi.org/10.17660/ ActaHortic.2015.1093.14

Deng, L., \& Deng, Q. (2018). The basic roles of indoor plants in human health and comfort. Environmental Science and Pollution Research, 25(36), 36087-36101. https://doi.org/10.1007/s11356-018-3554-1

Duan, J., Kang, J., Qin, W., Deng, T., Liu, H., Li, B., Yu, W., Gong, S., Yang, X., \& Chen, M. (2018). Exposure to formaldehyde and diisononyl phthalate exacerbate neuroinflammation through NF-кB activation in a mouse asthma model. Ecotoxicology and Environmental Safety, 163, 356-364. https://doi.org/10.1016/j.ecoenv.2018.07.089

Ge, S., Yan, B., Huang, J., Chen, Y., Chen, M., Yang, X., Wu, Y., Shen, D., \& Ma, P. (2019). Diisodecyl phthalate aggravates the formaldehydeexposure-induced learning and memory impairment in mice. Food and Chemical Toxicology, 126, 152-161. https://doi.org/10.1016/j. fct.2019.02.024

Ghaffarianhoseini, A., AlWaer, H., Omrany, H., Ghaffarianhoseini, A., Alalouch, C., Clements-Croome, D., \& Tookey, J. (2018). Sick building syndrome: Are we doing enough? Architectural Science Review, 61(3),99-121. https://doi.org/10.1080/00038628.2018.1461060

Gong, Y., Zhou, T., Wang, P., Lin, Y., Zheng, R., Zhao, Y., \& Xu, B. (2019) Fundamentals of ornamental plants in removing benzene in indoor 
air. Atmosphere, 10(4), 221. https://doi.org/10.3390/atmos10040221

Hadei, M., Hopke, P. K., Rafiee, M., Rastkari, N., Yarahmadi, M., Kermani, M., \& Shahsavani, A. (2018). Indoor and outdoor concentrations of BTEX and formaldehyde in Tehran, Iran: Effects of building characteristics and health risk assessment. Environmental Science and Pollution Research, 25(27), 27423-27437. https://doi.org/10.1007/s11356018-2794-4

Indoor Air Quality: Volatile Organic Compounds (VOCs). (2016, June 13). HealthLink BC. https://www. healthlinkbc.ca/healthlinkbc-files/airquality-VOCs

Jasmin, G. A., Noorizan, M., Suhardi, M., Murad, A. G., \& Ina, K. (2012). The use of plants to improve indoor air quality in small office space. Pertanika Journal of Social Science and Humanities, 20(2), 493-503.

Keith, K. (2011). Dangerous Decor: Consumer Knowledge of Health Risks within Interior Spaces. Master Dissertation. 3934. DOI: https://doi. org/10.31979/etd.fcru-2ubx

Kim, K. J., Kim, H. J., Khalekuzzaman, M., Yoo, E. H., Jung, H. H., \& Jang, H. S. (2016). Removal ratio of gaseous toluene and xylene transported from air to root zone via the stem by indoor plants. Environmental Science and Pollution Research, 23(7), 6149-6158. https://doi.org/10.1007/s11356-016-6065-y

Kim, Kwang Jin, Yoo, E. H., Jeong, M. I., Song, J. S., Lee, S. Y., \& Kays, S. J. (2011). Changes in the phytoremediation potential of indoor plants with exposure to toluene. HortScience, 46(12), 1646-1649. https:// doi.org/10.21273/hortsci.46.12.1646

Kwang, J. K., Mi, J. K., Jeong, S. S., Eun, H. Y., Son, K. C., \& Kays, S. J. (2008). Efficiency of volatile formaldehyde removal by indoor plants: Contribution of aerial plant parts versus the root zone. Journal of the American Society for Horticultural Science, 133(4), 521-526. https:// doi.org/10.21273/jashs.133.4.521

Mangkoedihardjo, S., \& Samudro, G. (2014). Research strategy on kenaf for phytoremediation of organic matter and metals polluted soil. Advances in Environmental Biology, 8(17), 64-67.

Masood, O. A. I., Al-Hady, M. I. A., \& Ali, A. K. M. (2017). Applying the Principles of Green Architecture for Saving Energy in Buildings. Energy Procedia, 115, 369-382. https://doi.org/10.1016/j.egypro.2017.05.034

Meng, G. Z., \& Ji, K. S. (2012). Comparisons of the capacity of 4 ornamental plants on purifying indoor formaldehyde pollution. Proceedings of International Conference on Information and Computing Science, IC/C, 225-227. https://doi.org/10.1109//CIC.2012.16

Nakaoka, H., Suzuki, N., Nakayama, Y., Takaya, K., Todaka, E., Tanaka, S., Matsushita, K., \& Mori, C. (2018). A preliminary study to investigate the relationship between indoor environment and its effect on physical and mental health. WIT Transactions on Ecology and the Environment, 230, 567-576. https://doi.org/10.2495/AIR180531

Nakaoka, H., Todaka, E., Seto, H., Saito, I., Hanazato, M., Watanabe, M., \& Mori, C. (2014). Correlating the symptoms of sick-building syndrome to indoor VOCs concentration levels and odour. Indoor and Built Environment, 23(6), 804-813. https://doi. org/10.1177/1420326X13500975

Nakayama, Y., Nakaoka, H., Suzuki, N., Tsumura, K., Hanazato, M., Todaka, E., \& Mori, C. (2019). Prevalence and risk factors of pre-sick building syndrome: Characteristics of indoor environmental and individual factors. Environmental Health and Preventive Medicine, 24, 77. https://doi.org/10.1186/s12199-019-0830-8

NASA Clean Air Study. (2020). In Wikipedia. https://en.wikipedia.org/w/ index.php?title=NASA_Clean_Air_Study\&oldid=995621199

Newman, L. A., \& Reynolds, C. M. (2004). Phytodegradation of organic compounds. Current Opinion in Biotechnology, 15(3), 225-230. https://doi.org/10.1016/j.copbio.2004.04.006

$\mathrm{Ni}$, J., Leung, A. K., \& Ng, C. W. W. (2019). Unsaturated hydraulic properties of vegetated soil under single and mixed planting conditions. Geotechnique, 69(6), 554-559. https://doi.org/10.1680/jgeot.17.T.044

Onesmo, B. M., \& Rongo, L. M. (2018). Assessment of respiratory symptoms and associated factors among house painters in kinondoni municipality tanzania. International Journal of Research -Granthaalayah, 6(1), 156-171. https://doi.org/10.29121/ granthaalayah.v6.i1.2018.1605

Painting, firefighting, and shiftwork. (2010). larc Monographs on the Evaluation of Carcinogenic Risks to Humans, 98, 9-764.

Pettit, T., Irga, P. J., \& Torpy, F. R. (2018). Towards practical indoor air phytoremediation: A review. Chemosphere, 208, 960-974. https:// doi.org/10.1016/j.chemosphere.2018.06.048

Pettit, T., Irga, P. J., \& Torpy, F. R. (2020). The evolution of botanical biofilters:
Developing practical phytoremediation of air pollution for the built environment. ICRBE Procedia, 116-129. https://doi.org/10.32438/ icrbe. 202012

Pryadko, I. (2018). Green Architecture as a Means of Sustainable Urban Development: Russian and International Experience. MATEC Web of Conferences, 193(258), 04015. https://doi.org/10.1051/ matecconf/201819304015

Ragheb, A., El-Shimy, H., \& Ragheb, G. (2016). Green Architecture: A Concept of Sustainability. Procedia - Social and Behavioral Sciences, 216, 778-787. https://doi.org/10.1016/..sbspro.2015.12.075

Ren, Y., Ge, Y., Ma, D., Song, X., Shi, Y., Pan, K., Qu, Z., Guo, P., Han, W., \& Chang, J. (2017). Enhancing plant diversity and mitigating BVOC emissions of urban green spaces through the introduction of ornamental tree species. Urban Forestry and Urban Greening, 27, 305-313. https://doi.org/10.1016/j.ufug.2017.08.011

Rovelli, S., Cattaneo, A., Fazio, A., Spinazzè, A., Borghi, F., Campagnolo, D., Dossi, C. \& Cavallo, D. M. (2019). VOCs measurements in residential buildings: Quantification via thermal desorption and assessment of indoor concentrations in a case-study. Atmosphere, 10(2), 57. https:// doi.org/10.3390/atmos10020057

Samudro, G., \& Mangkoedihardjo, S. (2020). Mixed plant operations for phytoremediation in polluted environments - A critical review. Journal of Phytology, 12, 99-103. https://doi.org/10.25081/jp.2020.v12.6454

Samudro, H., \& Mangkoedihardjo, S. (2020). Greening the environment in living a new lifestyle in the COVID-19 era. Eurasian Journal of Biosciences, 14(2), 3285-3290.

Sevik, H., Cetin, M., Guney, K., \& Belkayali, N. (2018). The effect of some indoor ornamental plants on $\mathrm{CO}_{2}$ levels during the day. Polish Journal of Environmental Studies, 27(2), 839-844. https://doi.org/10.15244/ pjoes $/ 76243$

Smith, A. J., Fsadni, A., \& Holt, G. (2017). Indoor living plants' effects on an office environment. Facilities, 35(9-10), 525-542. https://doi. org/10.1108/F-09-2016-0088

Suzuki, N., Nakaoka, H., Hanazato, M., Nakayama, Y., Takaya, K., \& Mori, C. (2019). Emission rates of substances from low-volatileorganic-compound paints. International Journal of Environmental Science and Technology, 16(8), 4543-4550. https://doi.org/10.1007/ s13762-018-2093-0

Teiri, H., Hajizadeh, Y., Samaei, M. R., Pourzamani, H., \& Mohammadi, F. (2020). Modelling the phytoremediation of formaldehyde from indoor air by Chamaedorea Elegans using artificial intelligence, genetic algorithm and response surface methodology. Journal of Environmental Chemical Engineering, 8(4), 103985. https://doi. org/10.1016/j.jece.2020.103985

Teiri, H., Pourzamani, H., \& Hajizadeh, Y. (2018a). Phytoremediation of VOCs from indoor air by ornamental potted plants: A pilot study using a palm species under the controlled environment. Chemosphere, 197, 375-381. https://doi.org/10.1016/j. chemosphere.2018.01.078

Teiri, H., Pourzamzni, H., \& Hajizadeh, Y. (2018b). Phytoremediation of formaldehyde from indoor environment by ornamental plants: An approach to promote occupants health. International Journal of Preventive Medicine, 9(1), 70. https://doi.org/10.4103/ijpvm. IJPVM 26916

van den Broekk, J., Klein Cerrejon, D., Pratsinis, S. E., \& Güntner, A. T. (2020). Selective formaldehyde detection at ppb in indoor air with a portable sensor. Journal of Hazardous Materials, 399, 123052. https://doi. org/10.1016/.j.jhazmat.2020.123052

Wang, H., Tseng, C., \& Hsieh, T. (2008). Developing an indoor air quality index system based on the health risk assessment. Environmental Engineering, August, 17-22.

Wang, L., Sheng, Q., Zhang, Y., Xu, J., Zhang, H., \& Zhu, Z. (2020). Tolerance of fifteen hydroponic ornamental plant species to formaldehyde stress. Environmental Pollution, 265, 115003. https:// doi.org/10.1016/j.envpol.2020.115003

Wang, Z., Pei, J., \& Zhang, J. S. (2014). Experimental investigation of the formaldehyde removal mechanisms in a dynamic botanical filtration system for indoor air purification. Journal of Hazardous Materials, 280 235-243. https://doi.org/10.1016/j.jhazmat.2014.07.059

Yang, D. S., Pennisi, S. V., Son, K. C., \& Kays, S. J. (2009). Screening indoor plants for volatile organic pollutant removal efficiency. HortScience, 44(5), 1377-1381. https://doi.org/10.21273/hortsci.44.5.1377

Zhang, B., Cao, D., \& Zhu, S. (2020). Use of plants to clean polluted air: A potentially effective and low-cost phytoremediation technology. 
Samudro and Mangkoedihardjo

BioResources, 15(3), 4650-4654. https://doi.org/10.15376/ biores.15.3.4650-4654

Zhang, L., Steinmaus, C., Eastmond, D. A., Xin, X. K., \& Smith, M. T. (2009). Formaldehyde exposure and leukemia: A new metaanalysis and potential mechanisms. Mutation Research - Reviews in Mutation Research, 681(2-3), 150-168. https://doi.org/10.1016/j. mrrev.2008.07.002

Zhou, C., Zhan, Y., Chen, S., Xia, M., Ronda, C., Sun, M., Chen, H., \& Shen, X. (2017). Combined effects of temperature and humidity on indoor VOCs pollution: Intercity comparison. Building and Environment, 121,
26-34. https://doi.org/10.1016/j.buildenv.2017.04.013

Zhou, J., Qin, F., Su, J., Liao, J. wu, \& Xu, H. lian. (2011). Purification of formaldehyde-polluted air by indoor plants of Araceae, Agavaceae and Liliaceae. Journal of Food, Agriculture and Environment, 9(3-4), 1012-1018.

Zorić, M., Simić, M., Orlović, S., Mladenović, E., \& Babić, Z. (2019). Indoor Ecosystem Services: Impacts of Plants on Air Quality. Contemporary Agriculture, 68(1-2), 12-16. https://doi.org/10.2478/ contagri-2019-0003 